\title{
Comments
}

\section{Early Normalization of Luteinizing Hormone Pulsatility after Successful Transsphenoidal Surgery in Women with Microprolactinomas}

\author{
A. STEVENAERT, A. BECKERS, J. L. VANDALEM, AND G. HENNEN \\ Clinique Neuro-chirurgicale, Hôpital de Bavière, and Endocrinologie Expérimentale et Clinique, Centre \\ Hospitalier Universitaire, Institut de Pathologie (A.B., J.L.V., G.H.), B23, 4000 Liege, Belgium
}

\begin{abstract}
In eight hyperprolactinemic amenorrheic women who had a microprolactinoma, LH secretion was examined by measuring its concentration in blood samples collected every $15 \mathrm{~min}$ for $6 \mathrm{~h}$ before and 8 days after successful selective adenomectomy. Computer analysis was used for LH peak evaluation. In both circumstances, serum PRL and basal estradiol $\left(E_{2}\right)$ levels were also determined. Before operation, the number of $L H$ peaks ranged from zero to one per $6 \mathrm{~h}$ in seven patients and was two per $6 \mathrm{~h}$ in the eighth patient. In all patients, serum PRL was normal on the eighth postoperative day, while $E_{2}$ levels remained low, similar to the values usually found in the early follicular phase of the cycle in normal women. Postoperatively,
\end{abstract}

mean LH levels were similar to preoperative levels, but there was a dramatic increase in the number of $\mathrm{LH}$ peaks (three to five per $6 \mathrm{~h}$ ) in five of the eight patients.

These observations confirm the impairment of LH pulsatility in hyperprolactinemia and demonstrate that normalization of PRL levels by surgery can restore LH pulsatile secretion in certain women as early as the eighth day after operation in the absence of a significant change in serum $E_{2}$ levels. Thus, the preoperative impaired pulsatility of $\mathrm{LH}$ secretion was probably a central effect of hyperprolactinemia. ( $J$ Clin Endocrinol Metab 62: 1044, 1986)
$\mathrm{T}$ HE MAIN disturbances provoked by hyperprolactinemia in the human concern the hypothalamopituitary-gonadal axis. In the rats, dopamine turnover in the median eminence is increased by hyperprolactinemia, probably by a short loop feedback $(1,2)$. In man, dopamine infusion reduces serum LH concentrations (3), as well as the frequency of LH pulses (4). Furthermore, hyperprolactinemia is associated with a reduction in frequency or absence of LH pulses (5-8). Normalization of PRL with bromocriptine is followed by restoration of LH pulsatility (5-8), but this action may be due to a central action of bromocriptine rather than a consequence of reduced PRL secretion.

Recently, LH pulsatility was found to be restored after transsphenoidal surgery (9). However, since that restoration occurred after resumption of menses and normal ovulatory function, it remained uncertain whether the postoperative increase in the number of $\mathrm{LH}$ peaks was due to PRL normalization or to an elevation of serum estradiol $\left(\mathrm{E}_{2}\right)$ levels. Indeed, the $\mathrm{LH}$ positive feedback response to estrogens is impaired in hyperprolactinemia (10) and restored after bromocriptine (11).

Received August 12, 1985

Address requests for reprints to: Dr. A. Beckers, Endocrinologie Experimentale, Centre Hospitalier Universitai, Institut de Pathologie, B23, Liege 4000, Belgium.
The present study was undertaken to determine whether 1) LH pulsatility is present in women with microprolactinomas, 2) the pattern of LH secretion is modified soon after successful adenomectomy, and 3) variations in LH secretion are related to changes in the serum $\mathrm{E}_{2}$ levels.

\section{Subjects and Methods}

\section{Study patients}

This consecutive series was composed of eight women referred to the Neurosurgical Clinic at the University of Liege for surgical treatment of their microprolactinomas. Surgery was undertaken because of lack of efficacy or side-effects of long term treatment with bromocriptine. All patients (Table 1) had amenorrhea-galactorrhea, elevated plasma PRL concentrations, and normal thyroid and adrenal function. The presence of microadenomas was established by sellar polytomography and high resolution computed tomographic scan. In all patients, an adenoma was later found by transsphenoidal surgery and was totally removed. The size of the adenomas was estimated by measuring the diameter of the cavity after tumorectomy. None of the patients had any postoperative complications; in particular, neither diabetes inspidus nor pituitary insufficiency was recorded.

\section{Methods}

The studies of pulsatile LH secretion were performed only after all patients had given informed written consent. On the 
TABLE 1. Clinical data from eight women with microprolactinomas

\begin{tabular}{ccccc}
\hline Patient no. & Age (yr) & $\begin{array}{c}\text { Duration of } \\
\text { amenorrhea } \\
(\mathrm{yr})^{a}\end{array}$ & $\begin{array}{c}\text { Diameter of } \\
\text { adenoma } \\
(\mathrm{mm})\end{array}$ & $\begin{array}{c}\text { Return of } \\
\text { menses } \\
\text { (weeks) }^{b}\end{array}$ \\
\hline 1 & 22.0 & 1.5 & 6 & 5 \\
2 & 20.9 & 1.0 & 8 & 5 \\
3 & 19.7 & 4.5 & 7 & 4 \\
4 & 22.8 & 7.0 & 10 & 4 \\
5 & 22.6 & 4.0 & 8 & 6 \\
6 & 37.2 & 7.0 & 10 & 6 \\
7 & 25.5 & 2.0 & 8 & 3 \\
8 & 20.5 & 4.5 & 5 & 4 \\
Mean \pm SD & $23.9 \pm 5.7$ & $3.9 \pm 2.3$ & $7.8 \pm 1.8$ & $4.6 \pm 1.1$
\end{tabular}

${ }^{a}$ Before surgery.

${ }^{b}$ After surgery.

day after admission, an indwelling cannula was inserted into a forearm vein at $0800 \mathrm{~h}$, and $5 \mathrm{ml}$ blood were drawn every 15 $\min$ for $6 \mathrm{~h}$. The serum was stored at $-20 \mathrm{C}$ for LH assays. In addition, blood samples were obtained for determinations of basal FSH, PRL, and $\mathrm{E}_{2}$ concentrations on 3 consecutive days. The protocol was carried out again on the eighth postoperative day. The patients did not receive any medications during the sampling periods.

\section{Assays}

Serum LH concentrations were determined using slight modifications of a very specific and sensitive RIA previously described (12). The data were analyzed on the basis of a weighted linear regression using Rodbard's programs (13). The minimum detectable dose ranged from $0.08-0.4 \mathrm{mIU} / \mathrm{ml}$. The slope of the standard curve was -1.02 to -1.16 , and the $\mathrm{ED}_{50}$ ranged from $2.23-3.61 \mathrm{mIU} / \mathrm{ml}$. In the range of $1-10 \mathrm{mIU} / \mathrm{ml}$ (corresponding to $20-80 \%$ bound to free ratio), the intraassay coefficient of variation ranged from 4.01-9.97\%. Mean LH values were calculated by averaging the results of the 25 blood samples drawn every $15 \mathrm{~min}$ for $6 \mathrm{~h}$. The pre- and postoperative sera from an individual woman were analyzed in the same LH assay. The standard curve was calibrated with the relevant international reference preparation (68/40; Medical Research Council, Mill Hill, London, England). Serum concentrations of $E_{2}$ and PRL were measured by RIA using commercial kits (NMS Pharmaceuticals, Inc., Newport Beach, CA; Techland, Liege, Belgium); mean values were obtained by averaging the results of the 3 blood samples.

\section{Analysis}

Significant LH peaks were identified with the Pulsar program (14), in connection with the MLAB system (15) running on a Digital Dec-20 computer. Briefly, this program first performs the baseline determination, taking into account possible long trends in the experimental series; the peaks are secondarily identified on the basis of both height and length. This is made through an iterative process. The program allows the user to define the value of some parameters that will be used for both baseline and peak determinations. In the present study, the width of the "smoothing window" (used for baseline definition) was fixed at $720 \mathrm{~min}$, and the following values of the $\mathrm{G}$ criteria were used for peak identification: $\mathrm{G} 1=3.8, \mathrm{G} 2=2.26, \mathrm{G} 3=$ $1.56, \mathrm{G} 4=1.13$, and $\mathrm{G} 5=0.83$. In these conditions, a variation in the experimental series is identified as a peak provided that such a variation exceeds 3.8 times the expected SD at this point if it concerns one experimental point only, 2.26 times the expected SD if it concerns two subsequent points, 1.56 times the expected SD for three subsequent points, etc. The expected SD at each concentration is computed by the program on the basis of the within-assay precision of the assay used for hormone determination.

\section{Results}

\section{Clinical data}

As shown in Table 1, the patients' ages ranged from 19.7-37.2 yr [mean, 23.9 $\pm 5.7( \pm \mathrm{SD}) \mathrm{yr}$ ], and the duration of amenorrhea ranged from 1-7 yr [mean, $3.9 \pm 2.3$ $( \pm \mathrm{SD}) \mathrm{yr}$. In all patients, radiological examination showed signs consistent with a microadenoma, which was subsequently proven at operation. The tumors all were less than $10 \mathrm{~mm}$ in diameter [mean, $7.8 \pm 1.8$ ( \pm SD) $\mathrm{mm}]$.

After operation, all women resumed normal menstrual cycles, with serum progesterone concentrations ranging from $4-28 \mathrm{ng} / \mathrm{ml}$ in the luteal phase. The first menses occurred 3-6 weeks after adenomectomy. The women had regular cycles during the follow-up (at least $1 \mathrm{yr}$ ). Two women, who desired pregnancy before operation, became pregnant and delivered a term baby.

\section{Hormone data}

As illustrated in Table 2, serum PRL concentrations were elevated in all patients before surgery and decreased significantly $(P<0.0005)$ to normal values $(1-14 \mathrm{ng} / \mathrm{ml})$ by 8 days after operation. In addition, the mean PRL level 6 months later $[7.1 \pm 1.6( \pm \mathrm{SD}) \mathrm{ng} / \mathrm{ml}] \mathrm{did}$ not differ from the mean level on the eighth postoperative day $(6.2 \pm 2.4 \mathrm{ng} / \mathrm{ml})$.

Preoperative serum $\mathrm{E}_{2}$ levels were similar to those seen during the early follicular phase $(14-90 \mathrm{pg} / \mathrm{ml})$ in normally cycling women, except in patient 7 in whom the level was slightly higher. The levels on the eighth postoperative day were not significantly different from the preoperative values.

Mean LH levels ranged from $0.24-9.9 \mathrm{mIU} / \mathrm{ml}$ before operation and from $0.99-5.89 \mathrm{mIU} / \mathrm{ml}$ after operation. There was no significant difference in pre- and postoperative mean values. The frequency of $\mathrm{LH}$ pulses was low in all patients before surgery (zero to two peaks per $6 \mathrm{~h})$. On the eighth postoperative day, a significant increase $(P<0.05)$ in $\mathrm{LH}$ pulses was achieved in the entire series. Results in one patient are shown in Fig. 1. 
TABLE 2. Pre- and postoperative hormone values from eight women with microprolactinomas

\begin{tabular}{|c|c|c|c|c|c|c|c|c|}
\hline \multirow{2}{*}{$\begin{array}{l}\text { Patient } \\
\text { no. }\end{array}$} & \multicolumn{4}{|c|}{ Preoperative } & \multicolumn{4}{|c|}{ Postoperative ( 8 days) } \\
\hline & $\begin{array}{c}\text { PRL } \\
(\mathrm{ng} / \mathrm{ml})\end{array}$ & $\begin{array}{c}\mathrm{E}_{2}(\mathrm{pg} / \\
\mathrm{ml})\end{array}$ & $\begin{array}{c}\mathrm{LH} \\
(\mathrm{mIU} / \mathrm{ml})\end{array}$ & $\begin{array}{c}\text { No. of } \\
\text { LH pulses }\end{array}$ & $\begin{array}{c}\text { PRL } \\
\text { (ng/ml) }\end{array}$ & $\begin{array}{c}\mathrm{E}_{2}(\mathrm{pg} / \\
\mathrm{ml})\end{array}$ & $\begin{array}{c}\mathrm{LH} \\
(\mathrm{mIU} / \mathrm{ml})\end{array}$ & $\begin{array}{c}\text { No. of } \\
\text { LH pulses }\end{array}$ \\
\hline 1 & 127.7 & 55 & 1.1 & 1 & 7.4 & 20 & 3.2 & 5 \\
\hline 2 & 41.3 & 15 & 4.81 & 1 & 3.2 & 30 & 5.18 & 4 \\
\hline 3 & 108.9 & 17 & 8.1 & 1 & 3.2 & 26 & 2.97 & 3 \\
\hline 4 & 86.2 & 40 & 0.4 & 0 & 5.3 & 40 & 2.73 & 3 \\
\hline 5 & 113.5 & 60 & 9.58 & 0 & 8.9 & 27 & 4.28 & 3 \\
\hline 6 & 72.4 & 14 & 0.24 & 2 & 7.4 & 40 & .99 & 1 \\
\hline 7 & 65.8 & 97 & 9.91 & 1 & 4.3 & 64 & 5.89 & 1 \\
\hline 8 & 77.0 & 44 & 2.16 & 1 & 10.2 & 29 & 4.21 & 0 \\
\hline Mean & 86.6 & 43 & 4.5 & & 6.2 & 34 & 3.7 & \\
\hline SD & 27 & 28 & 4.1 & & 2.4 & 14 & 1.5 & \\
\hline
\end{tabular}

PRL and $E_{2}$ mean values were from three blood samples; $L H$ mean values were from 25 blood samples.

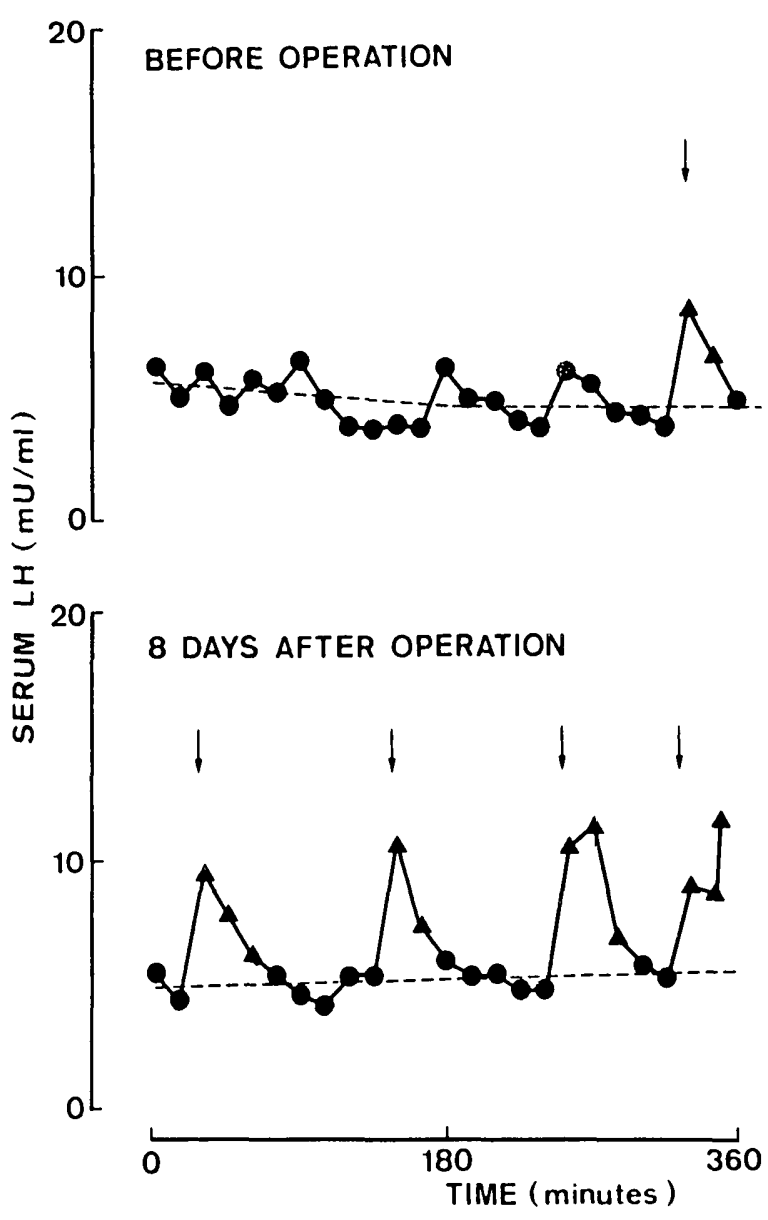

FIG. 1. Pre- and postoperative serum LH concentrations in patient 2. The start of a LH pulse is indicated by an arrow. $\Delta$, Points included in peaks. Baselines, as calculated by Pulsar, are shown (- - ).

\section{Discussion}

It is now well established that the secretion of pituitary gonadotropins is pulsatile in nature, that this pattern of secretion is of functional significance (16), and that LH pulsatility occurs in response to pulsatile $\mathrm{GnRH}$ release from the hypothalamus (17). In normally cycling women, the frequency of $\mathrm{LH}$ pulses varies with the stage of the menstrual cycle $(5,18-20)$.

Hyperprolactinemic amenorrheic women can have reduced frequency or absence of LH pulses (5-8), although they also may have a heterogeneous pattern (21). Normal LH pulsatility can be restored with bromocriptine treatment, resulting in PRL normalization $(6-8,21)$. Since it has been suggested that bromocriptine can directly affect $\mathrm{LH}$ release (22), it is not possible to assert with certainty that the restoration of $\mathrm{LH}$ pulsatility is exclusively due to PRL normalization.

Another method to evaluate the role of hyperprolactinemia in altering LH pulsatility would be to study $\mathrm{LH}$ secretory patterns before and after successful removal of prolactinomas. This method was applied in a recent study (9). However, in this report, postoperative restoration of LH pulsatility was documented 2-6 months after surgery, but the women had already had one or more normal menstrual cycles, inferring complete normalization of ovarian function, so this result was expected.

The present study, undertaken in a homogeneous group of amenorrheic hyperprolactinemic patients, evaluated the LH secretory pattern before operation for microadenoma and 8 days after surgery. At this time, the patients had normal PRL levels, but none had any change in estrogen secretion. Consequently, a possible role for estrogens in the restoration of LH pulsatility could be excluded. In five of eight amenorrheic hyperprolactinemic women, an increased frequency of LH pulsatility was found 8 days after successful excision of pituitary microadenoma compared to preoperative $\mathrm{LH}$ patterns. These changes occurred after PRL normalization and without any change in $\mathrm{E}_{2}$ concentrations. This finding suggests that the preoperative impaired pulsatility of LH secretion was a central effect of hyperprolactinemia.

\section{Acknowledgments}

The authors thank Mrs. Carine Mottard, Mrs. Anne-Marie Pleyers, Miss Marie-France Pirard, Mr. Marc Bertolini, and Mr. Guy Pirens 
for expert technical assistance; Mrs. Christine Sornin and Mrs. Annie Dockier for secretarial support; and the staff of the Neurosurgical Clinic for nursing assistance.

\section{References}

1. Hokfelt T, Fuxe K 1972 Effects of prolactin and ergot alkaloids on the tubero-infundibular dopamine (DA) neurons. Neuroendocrinology 9:100

2. Advis JP, Han T, Hodson GP, Mueller GP, Meites J 1977 Temporal relationship and role of dopamine in "short-loop" feedback of prolactin. Proc Soc Exp Biol Med 155:567

3. Leblanc H, Lachelin GCL, Abu-Fadil S, Yen SSC 1976 Effects of dopamine infusion on pituitary hormone secretion in humans. $J$ Clin Endocrinol Metab 43:668

4. Huseman CA, Kugler JA, Schneider IG 1980 Mechanism of dopaminergic suppression of gonadotrophin secretion in man. J Clin Endocrinol Metab 51:209

5. Santen RJ, Bardin CW 1973 Episodic luteinizing hormone secretion in men: pulse analysis, clinical interpretation, physiologic mechanisms. J Clin Invest 52:2617

6. Bonnet HG, Dahlen HG, Wuttke W, Schneider HPG 1976 Hyperprolactinaemic anovulatory syndrome. J Clin Endocrinol Metab 42:132

7. Moult PJA, Rees LH, Besser GM 1982 Pulsatile gonadotrophin secretion in hyperprolactinaemic amenorrhea and the response to bromocriptine therapy. Clin Endocrinol (Oxf) 16:153

8. Sander SE, Frager M, Case GD, Kelch RP, Marshall JC 1984 Abnormal patterns of pulsatile luteinizing hormone secretion in women with hyperprolactinemia and amenorrhea: responses to bromocriptine. J Clin Endocrinol Metab 59:941

9. Koizumi K, Aono T, Koite K, Kurachi K 1984 Restoration of LH pulsatility in patients with prolactinomas after transsphenoidal surgery. Acta Endocrinol (Copenh) 107:433

10. Glass MR, Shaw RW, Buh WL, Login-Edwards R, London DR 1975 An abnormality of estrogen feedback in amenorrhoea-galactorrhoea. Br Med J 3:274

11. Aono T, Migake A, Shigi T, Yasuda M, Koike K, Kurachi K 1979
Restoration of estrogen positive feedback effect on $\mathrm{LH}$ release by bromocriptine in hyperprolactinaemic patients with galactorrhoeaamenorrhoea. Acta Endocrinol (Copenh) 91:591

12. Vandalem JL, Pirens G, Closset J, Hennen G 1975 Selective radioimmunoassays for human luteinizing hormone (hLH) and human chorionic gonadotropin (hCG). Arch Int Physiol Biochem 83:753

13. Rodbard D, Frazier G 1973 Radioimmunoassay Data Processing, 2nd Ed Fortran IV-G Program listings (PB 217367) or Magnetic Tapes (PB 217366). National Technical Information Service, Springfield, VA

14. Merriam G, Wachter K 1982 Algorythms for the study of episodic hormone secretion. Am J Physiol 243:E310

15. Knott G, Reece D 1972 MLAB: a civilized curve fitting system. In: Proceedings of the Online '72 International Conference. Control of the Menstrual Cycle. Brunel University, England. vol 1:497

16. Knobil E 1980 Neuroendocrine control of the menstrual cycle. Recent Prog Horm Res 36:53

17. Carmel PW, Araki S, Ferin M 1976 Pituitary stalk portal blood collection in rhesus monkeys: evidence for pulsatile release of gonadotropin-releasing hormone $(\mathrm{GnRH})$. Endocrinology 99:243

18. Yen S, Tsai CC, Naftolin F, Vandenberg G, Abajor L 1972 Pulsatile pattern of gonadotropin release in subjects with and without ovarian function. J Clin Endocrinol Metab 34:671

19. Bäekstrom CT, McNeilly AS, Leask RM, Baird DT 1982 Pulsatile secretion of LH, FSH, prolactin, oestradiol and progesterone during the human menstrual cycle. Clin Endocrinol (Oxf) 17:29

20. Reame N, Sander SE, Kelch RP, Marshall JC 1984 Pulsatile gonadotropin secretion during the human menstrual cycle: evidence for altered frequency of gonadotropin-releasing hormone secretion. J Clin Endocrinol Metab 59:328

21. Klibanski A, Beitins IZ, Merriam GR, MacArthur JW, Zervas NT, Ridgway EC 1984 Gonadotropin and prolactin pulsations in hyperprolactinemic women before and during bromocriptine therapy. J Clin Endocrinol Metab 58:1141

22. Martin WH, Rogol AD, Kaiser DL, Thorner MO 1981 Dopaminergic mechanisms and luteinizing hormone (LH) secretion. II. Differential effects of dopamine and bromocriptine on LH release in normal women. J Clin Endocrinol Metab 52:650 